\title{
New Institutional Theory: Implementasi Anggaran Berbasis Kinerja Menuju Organisasi Yang Kompetitif Dan Berorientasi Pasar
}

\author{
Astutiningrum, Ali Djamhuri, Yeney Widya Prihatiningtias \\ Program Magister Akuntansi, Pascasarjana FEB, Universitas Brawijaya
}

Email: kitoety@gmail.com

\begin{abstract}
The purpose of this study was to understand the organizational changes that occurred after the adoption of the performance-based budgeting. Organizational change was analyzed from the perspective of the NIT with a research focus on the process of implement performance-based budgeting in dr. Iskak Tulungagung Hospital. The research strategy is a case study with a qualitative approach. Results of research indicate the occurrence of coercive isomorphism, as an effort to gain legitimacy, which is supported by mimetic ishomorphism, which attempts impersonation of another organization, although it is weak. The dominant symptom is normative ishomorphism, as indicated by the members of the organization normative belief that performance-based budgeting system is most appropriate for the characteristics of the hospital. The implementation of performance-based budgeting has encouraged the use of funds more effectively and efficiently, so that dr. Iskak Tulungagung likely to benefit in order to motivate organizations become morecompetitive and at the same time market-oriented.
\end{abstract}

Keywords: Organizational Changes, Performance-Based Budgeting, Hybrid Organization, New Institutional Theory.

\section{PENDAHULUAN}

Perubahan global dan modernisasi memberikan pengaruh yang cukup besar pada tingginya kesadaran masyarakat atas pentingnya kesehatan yang mendorong tuntutan atas meningkatnya kualitas pelayanannya. Sementara itu, sudah menjadi rahasia umum bahwa rumah sakit pemerintah yang diharapkan sebagai penyedia layanan kesehatan publik sering kali dikeluhkan sebagai tidak fleksibel, tidak bermutu, dan tidak sebaik rumah sakit swasta.

Stigma negatif pada kinerja rumah sakit pemerintah mendorongpemerintah untuk berbenah dengan pengadopsian sistem sektor swasta ke dalam pemerintahan. New Public Manajemen (NPM) adalah konsep yang menekankan perlunya pengadopsian beberapa praktik dan teknik manajemen sektor swasta untuk diterapkan ke dalam sektor publik (Hood, 1991). Inti dari perubahan berdasarkan konsep NPM ini adalah penerapan nilai-nilai dan alat manajemen sektor swasta ke dalam sektor publik dan penyampaian layanan publik melalui mekanisme pasar (Siddiquee, 2006). Tujuan yang ingin dicapai dari konsep NPM ini pencapaian efisiensi, efektivitas, transparansi, dan akuntabilitas sektor publik seperti yang terjadi di sektor swasta. Peningkatan transparansi dan akuntabilitas publik oleh lembaga-lembaga sektor publik secara otomatis juga memberikan perubahan terhadap konsep penganggaran, pelaporan, dan pengukuran kinerja. Pada intinya, konsep NPM menekankan pada anggaran berbasis kinerja dan akuntansi berbasis akrual, yang merupakan proses menuju "accountingization" yaitu diadopsinya teknik-teknik akuntansi dari sektor swasta (Hood, 1995).

Pengadopsian konsep NPM oleh pemerintah tercermin dari perubahan yang dilakukan pada pengelolaan rumah sakit yang dimilikinya. Keinginan pemerintah

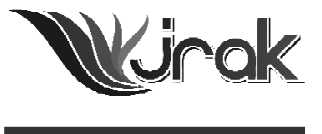

Jurnal Reviu Akuntansi dan Keuangan ISSN: 2088-0685 Vol.4 No. 2, Oktober 2014 Pp 595-606 
New

Institutional

Theory...

596 di Indonesia adalah untuk mengelola instansi rumah sakit seperti model pengelolaan di sektor swasta tanpa mengabaikan kepentingan negara, hal ini dapat dilihat dari pengelolaan ala swasta yang masih diatur dalam perundang-undangan sehingga dipilih model BLU/ BLUD yang menekankan pengadopsian sistem sektor swasta namun tetap berpegang pada karakteristik negara. Prinsip utama dari pembentukan rumah sakit sebagai BLUD ini adalah otonomi atau pengelolaan korporat ala perusahaanRumah sakit dapat dikelola sebagaimana layaknya sebuah perusahaan, meski bukan untuk mencari keuntungan. Salah satu konsekuensi rumah sakit yang berbentuk BLUD adalah kewajiban diterapkannya anggaran berbasis kinerja. Pengadopsian sistem anggaran berbasis kinerja di RSUD merupakan adopsi dari sistem manajemen sektor swasta yang relatif berbeda dengan sektor publik.

Perubahan bentuk organisasi pemerintah yang mengadopsi sistem manajemen sektor swasta ini lebih dikenal dengan istilah "quasi market" atau pasar pura-pura (Koppel, 2013). Pada intinya sistem manajemen sektor swasta dibawa ke ranah sektor publik karena dianggap memberikan hasil yang lebih efektif, efisien, dan kompetitif bagi organisasi. Istilah quasi market trasformation (QMT) diperkenalkan oleh Kitchener \& Whipp (1996) yang meneliti mengenai transformasi rumah sakit publik di Inggris, yaitu bergesernya penyelenggaraan layanan kesehatan dari monopoli oleh pemerintah dengan adanya penyedia lain, sehingga menjadi lebih kompetitif, dan mengakibatkan perubahan terhadap struktur dan sistem rumah sakit. Kajian Arndt \& Bigelow (2000) atas adopsi sistem pengelolaan bisnis swasta pada rumah sakit pemerintah di Amerika, menunjukkan hasil bahwa praktek-praktek swasta yang dilakukan ternyata tidak menjamin keberlangsungan rumah sakit meraih kesuksesan melalui kombinasi kompetitif, keuntungan, efisiensi operasi dan meningkatnya kualitas.

Beberapa penelitian, misalnyadi Amerika (Covaleski etal., 1993) dan (Chua \& Preston, 1994), di Mesir oleh Hassan (2005), di Australia oleh Abernethy et al., (2007), di Finlandia (Lehtonen, 2007) menunjukkan bahwa perubahan terjadi sangat lambat dan membutuhkan monitoring ketat serta dukungan dari berbagai pihak terkait untuk meraih keberhasilan. Penelitian lainnya di Italia oleh dan Stamatiadis dan Eriotis (2011) yang meneliti di rumah sakit pemerintah Yunani, menunjukkan bahwa akuntansi tidak hanya memiliki efek untuk aspek teknis/ ekonomis pelayanan kesehatan, tetapi juga berdampak pada aspek sosial, politik, serta perilaku dan budaya profesional.

Meski pemerintah telah mengambil kebijakan melalui Undang-undang No. 44 Tahun 2009 tentang Rumah Sakit bahwa seluruh rumah sakit pemerintah, baik pusat ataupun daerah, ke depan harus berbentuk BLUD. Pengelolaan keuangan rumah sakit sebagai SKPD yang menerapkan BLUD diatur oleh peraturan perundang-undangan di bidang keuangan negara. Berbagai peraturan mengenai BLUD tersebut menyatakan bahwa rumah sakit sebagai SKPD yang berbentuk BLUD diharuskan untuk menerapkan sistem anggaran berbasis kinerja dan akuntansi basis akrual.

Penerapan anggaran berbasis kinerja di sektor publik selain bertujuan meningkatkan akuntabilitas juga sekaligus sebagai upaya pemerintah untuk meningkatkan efektifitas dan efisiensi RSUD model BLUD dalam rangka meningkatkan daya saing. Menurut Blondal (2002) reformasi dan modernisasi proses anggaran telah menjadi trend di negara-negara anggota OECD dalam rangka untuk secara efektif mengontrol pengeluaran publik.Penelitian mengenai penerapan anggaran berbasis kinerja di sektor publik di antaranya dilakukan melalui studi literatur oleh Young (2003) mengenai penggunaan anggaran berbasis kinerja di negaranegara bagian di Amerika dan menunjukkan praktek yang berbeda-beda menurut aspek ekonomi, sosial, budaya maupun politik. Sementara Curristine $(2005,2007)$ mengulas tentang upaya negara-negara OECD berjuang menerapkan anggaran berbasis kinerja yang ternyata membutuhkan jalan yang panjang untuk menuju kesuksean. 
RSUD dr. Iskak Tulungagung adalah salah satu rumah sakit yang telah ditetapkan sebagai BLUD sejak Desember 2008 yang salah satu konsekuensinya adalah kewajiban penerapan anggaran berbasis kinerja. Adopsi anggaran berbasis kinerja sebagai sistem pengelolaan keuangan baru bagi RSUD dr. Iskak Tulungagung membawa dampak pada perubahan prosedur, proses, aturan dan tata kelola organisasi. Dengan kata lain, adopsi anggaran berbasis kinerja juga harus dipahami sebagai proses perubahan organisasi. Hal ini merujuk pada Jones (2001) yang menyebutkan bahwa perubahan organisasi merupakan sebuah proses berbagai organisasi beranjak dari keadaan yang sudah ada dan stabil kepada keadaan baru yang diinginkan dengan tujuan untuk meningkatkan efektivitas sehingga pada dasarnya organisasi melakukan perubahan menuju keadaan baru untuk meningkatkan efektivitas.

Penerapan sistem anggaran berbasis kinerja dalam PPK-BLUD adalah upaya RSUD dr. Iskak Tulungagung untuk memperoleh legitimasi. Djamhuri (2009) menyebutkan bahwa untuk memperoleh legitimasi, sebuah organisasi berupaya untuk melembagakan unsur-unsur lingkungan (ide, logika, praktik, teknik, dan kebiasaan) ke dalam organisasi, sehingga unsur-unsur lingkungan menjadi bagian dari organisasi tersebut. Pendekatan ekonomi kelembagaan pada awalnya menggunakan asumsi-asumsi rasionalitas klasik dengan asumsi-asumsi ekonomi untuk mewujudkan eksistensi organisasi dan institusi.

Dalam perspektif New Institutional Theory (NIT), upaya menyesuaikan diri sehingga mirip dengan lingkungannya ini dikenal sebagai isomorphism. Selanjutnya, menurut Di Maggio dan Powell (1983) serta Carruthers (1995) ada tiga cara yang dilakukan oleh organisasi untuk menjadi mirip (isomorphism) dengan lingkungan kelembagaannya, yakni coercive, proses penyesuaian terkait dengan tekanan formal yang bersifat "pemaksaan" kepada organisasi untuk melakukan perubahan; mimetic yang menghubungkan proses perubahan organisasi dengan upaya meniru kesuksesan organisasi sejenis; dan selanjutnya normative isomorphism yang menekankan profesionalisasi organisasi sebagai faktor pendorong perubahan. Norma atau sesuatu yang tepat bagi organiasi berasal dari pendidikan formal dan sosialisasi pengetahuan formal itu di bidang tertentu yang menyokong dan menyebarkan kepercayaan normatif itu. Ketika profesionalisme meningkat maka tekanan normatif juga akan meningkat.

Berangkat dari berbagai hal di atas, penulis menganggap bahwa New Institutional Theory (NIT) dapat digunakan sebagai alat analisis untuk memahami bagaimana sebuah rumah sakit menerapkan anggaran berbasis kinerja dalam organisasinya. Hal ini sesuai dengan hasil penelitian beberapa peneliti sebelumnya yang menunjukkan bahwa akuntansi tidak hanya dipengaruhi oleh lingkungannya namun juga mempengaruhi lingkungannya, dalam hal ini organisasi. Perubahan organisasi yang ditimbulkan akuntansi dapat dipahami dan dianalisis dengan menggunakan NIT (Carruthers,1995, Lippi, 2000).

\section{METODE}

Penelitian ini menggunakan pendekatan kualitatif dengan model penelitian studi kasus di bawah paradigma post-positivis. Yin (2004) menjelaskan bahwa studi kasus merupakan suatu penelitian empirik yang menyelidiki keadaan yang terjadi pada masa sekarang dalam realita kehidupan yang bersifat nyata, ketika batas antara gejala dengan latar tidak secara jelas terbukti, dan bilamana berbagai sumber bukti digunakan. Model studi kasus dipilih karena peneliti ingin mendapatkan diskripsi yang jelas, dan mendalam tentang respon organisasi yang terjadi dalam proses pengadopsiaan anggaran berbasis kinerja di RSUD dr. Iskak Tulungagung. Menurut Setioko (2011), pendekatan kualitatif dengan metode studi kasus digunakan apabila tujuan penelitian adalah untuk mendapatkan diskripsi yang jelas dan mendalam tentang suatu peristiwa yang nuansanya terikat sangat kental 
New

Institutional

Theory... dengan tempat dan waktu. Paradigma post-positivis dipilih karena lebih mampu mengantarkan pada tingkat pemahaman yang lebih mendalam atas realita sosial yang majemuk dan komplek dibanding dengan paradigma positivis.

Bagaimana perubahan organisasi yang terjadi selama proses penerapan anggaran yang terjadi di RSUD dr. Iskak Tulungagung berlangsung adalah sorotan utama dalam penelitian ini. Teori yang digunakan sebagai alat analisis dalam penelitian ini adalah New Instituttional Theory (NIT) yang dikenal karena penegasannya atas organisasi hanya sebagai simbol dan ritual. Jenis data dalam penelitian ini adalah data primer dan sekunder. Data primer diperoleh langsung dari informan melalui wawancara dan pengamatan, dan data sekunder diperoleh peneliti secara tidak langsung. Dalam penelitian ini wawancara dilakukan dengan mengajukan pertanyaan-pertanyaan kepada para informan yang telah ditentukan, yaitu pihak-pihak yang terlibat langsung dalam penerapan sistem anggaran berbasis kinerja di RSUD dr. Iskak Tulungagung. Data sekunder diperoleh dari dokumen-dokumen yang sudah tersedia. Dokumen-dokumen yang digunakan dalam penelitian ini di antaranya berupa Rencana Strategis Bisnis (Renstra), Rencana Bisnis Anggaran (RBA), dan Dokumen Perencanaan.

Teknik pengumpulan data yang dilakukan pada inipenelitian dilakukan dengan cara observasi (pengamatan), wawancara, dokumentasi dan triangulasi. Dalam penelitian ini peneliti tidak hanya menjadi pengamat yang pasif, namun pengamatan yang dilakukan adalah pengamatan semi aktif, sehingga peneliti juga berperan dalam situasi tertentu terhadap objek penelitian. Metode wawancara dilakukan dengan cara melakukan wawancara secara langsung dan mendalam (indepth interview) kepada informan, yaitu pihak-pihak yang terlibat dan terkait langsung dengan fokus penelitian, sehingga mendapatkan penjelasan mengenai situasi dan kondisi yang sebenarnya. Informan kunci yang dipilih dalam penelitian ini adalah pihak-pihak yang terkait dengan penerapan sistem anggaran berbasis kinerja. Dokumentasi dilakukan peneliti untuk memperoleh data-data tertulis yang terkait dengan proses penerapan anggaran berbasis kinerja di RSUD dr. Iskak Tulungagung. Dalam penelitian ini triangulasi dilakukan dengan memberikan pertanyaan mengenai hal yang sama kepada informan yang berbeda-beda, kemudian mencocokkan jawaban masing-masing informan, sehingga diperoleh keyakinan bahwa informasi yang diberikan dapat diyakini konsistensinya. Triangulasi juga dilakukan dengan membandingkan jawaban dari informan dengan dokumen-dokumen tertulis yang sudah ada, sehingga hasil wawancara dapat diyakini kebenarannya. Triangulasi ini sekaligus sebagai cara untuk melakukan pemeriksaan keabsahan data dan menguji kredibilitas penelitian.

Pada penelitian ini, analisis data akan dilakukan menggunakan konsep New Institutional Theory (NIT) untuk mendapatkan kesimpulan, yaitu dengan mengamati dan menemukan terjadinya gejala-gejala yang menunjukkan institutional isomorphism (coercive, mimetic, dan normative) sebagaimana diuraikan dalam NIT. DiMaggio dan Powell (1991) menyatakan bahwa munculnya isomorphism diakibatkan adanya tekanan institusional (institutional pressures) yang dapat dikelompokkan menjadi tiga, yaitu: 1) coercive pressures atau coercive isomorphism, 2) mimetic pressures atau mimetic isomorphism, 3) normative pressures atau normative isomorphism. Organisasi akan melihat suatu tekanan yang dianggap paling dominan sehingga mendorong organisasi untuk memilih tindakan isomorphism yang sesuai dengan arah dari jenis tekanan tersebut. Identifikasi terjadinya isomorphism dalam penelitian ini dilakukan dengan melihat bagaimana proses penerapan anggaran berbasis kinerja dilakukan.Hasil dari proses analisis data di atas, selanjutnya akan dihubungkan dan dicari keterkaitannya untuk merumuskan simpulan penelitian ini. 


\section{Pemahaman Penyusun Anggaran atas Angggaran Berbasis Kinerja}

Penyusunan anggaran adalah sebuah proses yang telah terbiasa dilakukan oleh RSUD dr. Iskak Tulungagung sejak lama. Sebagai SKPD penyusunan anggaran dilakukan sesuai dengan ketentuan yang ada mengikuti pemerintah daerah yang menaunginya. Penyusunan anggaran dalam pemerintahan di Indonesia telah mengalami perkembangan mulai dari penerapan anggaran tradisional sampai anggaran dengan pendekatan berbasis kinerja. Meski pendekatan anggaran berbasis kinerja telah cukup lama disosialisasikan, namun dalam praktek di lapangan aparatur pemerintah masih lebih familier dengan penggunaan anggaran tradisional, begitu juga dengan RSUD dr. Iskak Tulungagung.Menurut Lewin (1951), selalu akan ada berbagai kekuatan yang menentang adanya perubahan selain kekuatan yang menginginkan dilakukannya perubahan. Teori force field theory of change menggambarkan dinamika perubahan yang terjadi dalam suatu organisasi, meskipun kedua kekuatan ini selalu bertentangan namun di suatu waktu akan terjadi keseimbangan di antara kedua kekuatan tersebut (Lewin, 1951).

Bukan hal yang mudah untuk merubah pandangan lama yang telah diyakini para penyusun anggaran ini. Diperlukan waktu yang lama dalam usaha mengubah pola pikir yang telah "mendarah daging" sejak dulu. Namun karena komitmen pimpinan dan beberapa pejabat teknis yang menyadari manfaat penerapan anggaran berbasis kinerja ini, hal tersebut dianggap sebagai tantangan untuk menyusun anggaran yang lebih akurat. Menurut Burnes (1997) pilihan manajemen untuk berubah merupakan proses yang dipengaruhi oleh pengalaman masa lalu dan rencana di masa depan organisasi.

Dalam 3 (tiga) tahun terakhir, paradigma para penyusun anggaran telah banyak mengalami perubahan dengan dilakukannya pendampingan, pelatihan, dan sosialisasi yang berkesinambungan.Bagi para penyusun anggaran di RSUD dr. Iskak Tulungagung, anggaran berbasis kinerja dipahami sebagai anggaran yang disusun dengan memperhatikan usulan dari unit kerja terkecil, kemudian dipilah dan dipilih sesuai prioritas anggaran yang telah ditentukan. Sehingga anggaran yang disusun merupakan cerminan dari kebutuhan yang akurat dan akan digunakan tepat sesuai dengan sasaran yang diharapkan.

Pemahaman tersebut di atas telah sesuai dengan definisi Performance Based Budgeting yaitu sistem penganggaran yang berorientasi pada output organisasi dan berkaitan sangat erat dengan visi, misi dan rencana strategis organisasi (Bastian, 2006). Sementara menurut Mardiasmo (2009) anggaran yang berorientasi pada kinerja adalah sistem penganggaran yang berorientasi pada tujuan dan sasaran kinerja. Ciri utama Performance Based Budgeting adalah anggaran yang disusun dengan memperhatikan keterkaitan antara pendanaan (input) dan hasil yang diharapkan (outcomes), sehingga dapat memberikan informasi tentang efektivitas dan efisiensi kegiatan.

\section{Penerapan Anggaran Berbasis Kinerja di RSUD dr. Iskak Tulungagung}

Proses pelembagaan terhadap anggaran berbasis kinerja dimulai sejak penetapan status RSUD dr. Iskak Tulungagung sebagai BLUD yang menimbulkan kewajiban untuk melalukan PPK-BLUD, dengan konsekuensi penerapan sistem anggaran berbasis kinerja.Penyusunan RBA merupakan bentuk penerapan anggaran berbasis kinerja yang paling riil sehingga RSUD dr. Iskak Tulungagung berusaha untuk melaksanakannya. Beberapa penelitian (Young, 2003; Curristine, 2005, 2007) menunjukkan jalan panjang yang harus ditempuh untuk kesuksesan penerapan anggaran berbasis kinerja di sektor publik. Meskipun penyusunan RBA merupakan sesuatu yang relatif baru namun karena ketentuan dalam peraturan mewajibkan SKPD berbentuk BLUD untuk menerapkan, maka hal ini tidak dapat ditunda-tunda lagi. 
New

Institutional

Theory...

600
Penggunaan anggaran berbasis kinerja dalam penyusunan RBA dilegalkan melalui UU Nomor 1 tentang Perbendaharaan Negara, PP Nomor 23 Tahun 2005 tentang Pedoman Teknis Pengelolaan Keuangan Badan Layanan Umum dan terbitnya Peraturan Menteri Dalam Negeri No 61. Tahun 2007 tentang Pedoman Teknis Pengelolaan Keuangan Badan Layanan Umum Daerah. Peraturan ini secara tegas mewajibkan BLUD untuk menyusun RBA, meski belum memuat prosedur rinci tentang mekanisme penyusunannya.Sampai tahun 2015, RSUD dr. Iskak Tulungagung dengan segala kemampuan dan keterbatasannya berusaha keras untuk melaksanakan penyusunan RBA.

\section{Upaya Memperoleh Legitimasi}

Penyusunan RBA RSUD dr. Iskak Tulungagung dimulai pada tahun 2009 dengan dibentuknya Tim Penyusun Anggaran dengan didampingi Tim Pendamping Implementasi PPK-BLUD dari BPKP. Pada dasarnya penyusuan RBA pada saat itu hanya sebagai pemenuhan kewajiban untuk mengusun RBA, sebagimana diatur dalam Permendagri Nomor 61 Tahun 2007 karena penetapan RSUD sebagai BLUD saja. Pada periode tahun 2009 - 2011, penyusunan RBA dilakukan sekedar menyesuaikan dengan format yang diwajibkan, namun pola pikir aparatur mengenai proses penyusunannya sendiri masih belum berubah. Hasil Wawancara dengan informan juga menyatakan bahwa penyusunan RBA saat itu bukan atas pertimbangan manfaat, tetapi hanya sekedar memenuhi kewajiban karena kekhawatiran akan dicabutnya status BLUD.

Kepatuhan RSUD dr. Iskak Tulungagung untuk menerapkan PPK-BLUD sesuai dengan peraturan tersebut dapat dianggap sebagai salah satu upaya untuk memperoleh legitimasi. Hal ini menunjukkan bahwa faktor eksogen dalam bentuk coercive telah terjadi. DiMaggio dan Powell (1983) menyebutkan bahwa coercive isomorphism terjadi karena adanya faktor kekuasaan yang mengikat. Kasus pada penelitian ini menggambarkan bagaimana negara memberikan serangkaian aturan yang mengikat bagi instansinya. Coercive Isomorphism, adalah isomorphism yang terjadi akibat adanya tekanan-tekanan formal ataupun informal yang diterima suatu organisasi. Tekanan tersebut berasal dari organisasi lainnya ataupun dari harapan-harapan kultural di masyarakat sekitar tempat organisasi tersebut berada.

Dalam perkembangannya, karena proses penyusunan anggaran dengan format RBA dianggap paling sesuai dengan karakteristik rumah sakit, tumbuh keinginan yang kuat dari direksi dan seluruh jajarannya untuk menerapkan anggaran berbasis kinerja tanpa adanya tekanan dari pihak luar lagi, melainkan dari kesadaran internal organisasi. Hal ini menunjukkan kurangnya pengaruh tekanan peraturan dalam penerapan anggaran berbasis kinerja, sehingga bisa disimpulkan bahwa coercive isomorphism ini merupakan isomorphism yang lemah. Bagi RSUD dr. Iskak Tulungagung, kewajiban terhadap pemenuhan tuntutan formal regulasi bukan lagi menjadi tujuan utama dalam penyusunan RBA, tetapi pemahaman bahwa penyusunan RBA yang disesuai dengan kebutuhan anggaran akan memberikan peluang bagi rumah sakit untuk lebih maju dan berkembang adalah lebih penting.

\section{Upaya untuk Meniru Praktik Terbaik}

Salah satu hambatan yang dihadapi selama proses penyusunan RBA, adalah kurangnya pemahaman para aparatur terutama penyusun anggaran mengenai teknis penyusunan RBA. Beberapa penelitian (Hopwood, 1990; Hassan, 2005) menunjukkan bahwa perubahan sistem akuntansi, termasuk anggaran, dalam dunia yang kompleks dan saling tergantung bukanlah sesuatu yang mudah untuk diperkenalkan. Hingga tahun 2011 pola pikir penyusun anggaran masih belum memahami filosofi anggaran berbasis kinerja.

Untuk mengatasi kesenjangan informasi antara peraturan yang ada dan teknis pelaksanaan penyusunan RBA,RSUD dr. Iskak Tulungagung merasaperlu 
melakukan diskusi dengan organisasi lain yang sejenis. Diskusi dengan beberapa RSUD yang sejenis dilakukan dalam Rapat Koordinasi Pemantapan Implementasi Pola Pengelolaan Keuangan Badan Layanan Umum Daerah (BLUD) Kabupaten/ Kota se Jawa Timuruntuk menyamakan persepsi. Selain itu, pihak manajemen RSUD dr. Iskak Tulungagung juga mengundang beberapa narasumber ahli yang memiliki kompetensi mengenai penyusunan RBA untuk melakukan diskusi dan sosialisasi mengenai bagaimana praktek penyusunan RBA sesuai yang diamanatkan Permendagri Nomor 61 Tahun 2007 tersebut.

Usaha berdiskusi dengan institusi sejenis untuk menyamakan persepsi dan studi banding yang dilakukan RSUD dr. Iskak Tulungagung mencerminkan terjadinya mimetic ishomorphism dalam proses penerapan anggaran berbasis kinerja dalam penyusunan RBA, yaitu upaya untuk meniru praktik yang telah ada pada organisasi lain. Mimetic isomorphism menurut DiMaggio dan Powell (1983) adalah isomorphism yang terjadi ketika sebuah organisasi meniru praktek yang ada pada organisasi lain yang dinilai lebih baik dan berhasil. Mimetic ishomorphism biasanya melengkapi dorongan isomorphism lain yang terlebih dahulu ada.

Kenyataan bahwa peniruan tersebut tidak dilakukan secara keseluruhan, melainkan disesuaikan dengan situasi dan kondisi yang dihadapi RSUD dr. Iskak Tulungagung, menunjukkan bahwa mimeticisomorphismmerupakan gejala isomorphism yang lemah dalam proses penerapan anggaran berbasis kinerja di RSUD dr. Iskak Tulungagung.Scott (2014) menguraikan mengenai pengaruh terjadinya mekanisme ini dengan menyebutkan bahwa peniruan dalam proses institusionalisasi kemungkinan akan membawa dampak berupa kejelasan dan kepastian atau justru menimbulkan kebingungan dalam organisasi itu sendiri. Hasil diskusi dengan beberapa rumah sakit BLUD lain mendapatkan kejelasan mengenai tindakan-tindakan yang sebaiknya dilakukan dalam proses penyusunan RBA. Salah satu hal yang dianggap paling berpengaruh dalam keberhasilan penyusunan RBA di rumah sakit BLUD adalah penerapan anggaran partisipatif, yaitu keterlibatan setiap unit kerja dalam proses perencanaan anggaran.

\section{Perubahan dalam Konteks Normatif: Meningkatnya Komitmen Organisasi dan Partisipasi Anggaran dalam Penyusunan RBA}

Pemerintah daerah sebagai owner, dalam hal ini Kepala Daerah (Bupati) telah menetapkan RSUD dr. Iskak Tulungagung sebagai BLUD dengan tujuan agar pengelolaan rumah sakit lebih efektif, efisien, produktif, transparan, dan akuntabel. Berkat sosialisasi yang dilakukan terus menerus, maka para aparatur yang terlibat dalam proses penyusunan anggaran mulai mendapatkan pemahaman baru mengenai filosofi anggaran berbasis kinerja. RSUD dr. Iskak Tulungagung mulai dari direktur hingga seluruh jajaran di bawahnya memilih berkomitmen untuk menerapkan anggaran berbasis kinerja dalam penyusunan RBA.

Komitmen organisasi adalah komitmen atau kesepakatan yang dilakukan antara Direktur RSUD dr. Iskak Tulungagung beserta seluruh komponen organisasi dalam melaksanakan tugas pokok dan fungsi organisasinya untuk keberhasilan melaksanakan visi, misi, tujuan, sasaran, sesuai dengan rencana strategik (renstra) BLUD. Menurut Mowday et al. (1982) mengatakan bahwa karyawan yang memiliki komitmen organisasi yang tinggi akan lebih termotivasi untuk hadir dalam organisasi dan berusaha mencapai tujuan organisasi. Komitmen organisasi ditunjukkan dengan partisipasi yang diberikan oleh unit-unit kerja terkecil sebagai pelaksana anggaran dalam proses penyusunan RBA.

Mulai tahun 2014, prosedur dalam penyusunan RBA RSUD dr. Iskak Tulungagung telah dilakukan dengan menggunakan kombinasi top-down dan bottom-up. Perencanaan anggaran dilakukan secara berjenjang dengan melibatkan unit-unit kerja pelaksana anggaran sebagai pihak yang mengetahui secara langsung kegiatan operasional sehingga diperoleh informasi yang lebih akurat kebutuhan masing-masing unit kerja. Siegel dan Marconi (1989), menyatakan bahwa partisipasi manajer dalam penyusunan anggaran akan menimbulkan ini- 
New

Institutional

Theory...

602

siatif pada mereka untuk menyumbangkan ide dan informasi, meningkatkan kebersamaan dan merasa memiliki, sehingga kerjasama di antara anggota dalam mencapai tujuan juga ikut meningkat.

Perencanaan kegiatan tahunan dalam penyusunan RBA diawali dengan perhitungan target penerimaan/pendapatan oleh masing masing unit kerja sebagai dasar pembuatan rencana pengeluaran/pembiayaan. Keterlibatan individu-individu yang mempunyai pengaruh terhadap penyusunan target anggaran yang akan dievaluasi dan perlu penghargaan atas pencapaian target anggaran tersebut dapat dikatakan sebagai partisipasi anggaran (Brownell, dalam Putranto, 2012). Partisipasi anggaran (budgetary participation) merupakan proses ketika satuan kerja baik itu atasan maupun bawahan yang terlibat dan mempunyai pengaruh dalam menentukan target anggaran.

Komitmen organisasi yang tinggi dan partisipasi anggaran diharapkan akan meningkatkan kinerja RSUD dr. Iskak Tulungagung sehingga pelaksanaan anggaran akan lebih efektif dan efisien.

Gejala normativeishomorphism tampak dari adanya berbagai upaya dari anggota organisasi untuk menentukan kondisi dan metode kerja dalam proses penyusunan anggaran, yaitu keterlibatan semua pihak yang terkait penggunaan anggaran. Normative ishomorphismini merupakan gejala yang paling dominan dalam proses penyusunan RBA, yaitu isomorphism yang menekankan profesionalisasi organisasi sebagai faktor pendorong perubahan. Norma atau sesuatu yang tepat bagi organiasi berasal dari sosialisasi yang menyokong dan menyebarkan kepercayaan normatif itu. Anggaran berbasis kinerja dianggap paling sesuai dengan karakteristik rumah sakit yang sangat kompleks sehingga mampu memberikan manfaat dalam efektifitas pelaksanaan anggaran. Kesadaran organisasi akan manfaat penerapan anggaran berbasis kinerja dalam penyusunan RBA mendorong organisasi untuk terlibat secara aktif mewujudkan keberhasilan penerapan anggaran berbasis kinerja dalam penyusunan RBA.

\section{Penerapan Anggaran Berbasis Kinerja Sebagai Pendorong Perubahan Organisasi}

Perubahan organisasi adalah sebuah proses yang disengaja dan berorientasi pada tujuan tertentu yang disebabkan karena adanya tuntutan atau tekananan seperti tuntutan dari tenaga kerja, perkembangan teknologi, krisis ekonomi, kompetisi, kecenderungan sosial dan politik dunia (Robbins \& Judge, 2015). Penerapan anggaran berbasis kinerja di RSUD dr. Iskak Tulungagung adalah upaya untuk meningkatkan kinerja pengelolaan keuangan BLUD sesuai tuntutan dalam peraturan yang ada.

Proses penerapan sistem anggaran berbasis kinerja dalam penyusunan RBA RSUD dr. Iskak Tulungagung ini mampu mendorong perubahan organisasi yang dapat diketahui dengan terjadinya beberapa hal berikut: Pertama, perubahan SDM. Hal ini ditunjukkan dengan a) dibentuknya tim pengelola anggaran (Tim RKA) yang bertanggungjawab dalam penyusunan RBA; b) peningkatan kompetensi tim pengelola anggaran keuangan dilakukan dengan mengirimkan pegawai untuk mengikuti bimtek, workshop, dan pelatihan; c) update knowledge dengan melakukan studi banding dan/atau benchmarking dengan institusi sejenis yang lebih dulu atau dianggap telah berhasil menyusun RBA agar tidak ketinggalan informasi.

Kedua, perubahan prosedural. Hal ini dapat dilihat dari a) ditetapkannya perencanaan anggaran berjenjang dengan menerapkan kombinasi top-down dan bottom-up, yaitu dengan sistem melibatkan unit-unit kerja untuk mengajukan usulan anggaran pada bidang sesuai tugas pokok dan fungsi masing-masing. b) untuk mengoptimalkan partisipasi unit-unit kerja tersebut digunakan nota dinas untuk penyampaian usulan anggaran. Ketiga, perubahan nilai-nilai manajemen. Hal ini ditunjukkan dengan perubahan pemahaman tentang manfaat penerapan 
anggaran berbasis kinerja sehingga mendorong partisipasi aktif unit-unit kerja pelaksana anggaran.

Pada dasrnya pembentukan BLUD adalah upaya pemerintah untuk memindahkan tanggung jawab pelayanan publik dari lembaga pemerintah tradisional kepada instansi pemerintah yang dikelola seperti di sektor swasta, yang lebih dikenal dengan istilah organisasi hibrida (hybrid organization). Tidak seperti instansi pemerintah biasa, organisasi hibrida juga memiliki tujuan eksplisit nonpublik (misalnya, profitabilitas) dan menciptakan kewajiban keuangan bagi pemerintah (Koppel, 2003). Organisasi hibrida yang memadukan sistem manajemen publik dengan sistem manajemen swasta akan mengubah struktur organisasi, sehingga membentuk preferensi-preferensi kelompok kepentingan (stakeholders) dan hal ini dapat mendorong terjadinya perubahan dalam organisasi (Koppel, 2003). Sementara Hassan (2005) menyatakan bahwa perubahan terhadap sistem akuntansi menimbulkan kekhawatiran akan kemungkinan terjadinya privatisasi rumah sakit umum.

Menurut Koppell (2003) kebijakan pemerintah untuk membentuk hybrid organization, memberikan banyak kontribusi dalam memberikan pelayanan kepada publik, namun juga memicu hilangnya kontrol pemerintah atas kebijakan publik. Akibatnya, sebagai pengganti lembaga pemerintah daerah yang bertanggung jawab terhadap pelayanan publik RSUD dr. Iskak Tulungagung mulai bertindak dan menggunakan mekanisme berorientasi pasar untuk mencapai tujuan kebijakan publik yang didelegasikan kepadanya. Bukan lagi memberikan pelayanan kepada publik dalam bidang kesehatan yang akan menjadi tujuan utama rumah sakit, tetapi penyediaan layanan kesehatan sesuai peluang dan tuntutan pasar. Dalam rangka untuk mendapatkan keuntungan yang lebih tinggi, maka pengembangan yang dilakukan RSUD dr. Iskak Tulungagung lebih ditujukan kepada penyediaan layanan kesehatan yang lebih bagus sesuai dengan permintaan masyarakat. Hal ini menunjukkan perubahan RSUD dr. Iskak Tulungagung menjadi lebih berorientasi pada permintaan pasar.

Salah satu dampak paling menonjol dari penerapan anggaran berbasis kinerja di RSUD dr. Iskak Tulungagung adalah keleuasaan untuk menyusun anggaran sesuai dengan kebutuhan, sehingga penggunaan dana lebih efektif dan efisien. Efektifitas Hal ini memberikan kepercayaan diri yang tinggi bagi RSUD dr. Iskak Tulungagung untuk lebih mengembangkan diri dan bersaing dengan rumah sakit lain.Efektifitas dan efisiensi dana memungkinkan umah sakit untuk mendapatkan keuntungan yang dapat digunakan untuk mengembangkan diri dan mendorong organisasi menjadi lebih kompetitif dan sekaligus berorientasi pasar. Hasil ini mendukung penelitian oleh Kitchener \& Whipp (1996) mengenai transformasi rumah sakit publik di Inggris yang dikenal dengan istilah quasi market trasformation (QMT), yaitu bergesernya penyelenggara layanan kesehatan dari monopoli oleh pemerintah dengan adanya penyedia lain, sehingga lebih kompetitif.

\section{SIMPULAN}

Proses pelembagaan terhadap anggaran berbasis kinerja dimulai sejak penetapan status RSUD dr. Iskak Tulungagung sebagai BLUD. Penyusunan RBA merupakan bentuk penerapan anggaran berbasis kinerja yang paling riil sehingga RSUD dr. Iskak Tulungagung berusaha untuk melaksanakannya. Hasil penelitian di lapangan menunjukkan bahwa penggunaan anggaran berbasis kinerja dalam proses penyusunan RBA di RSUD dr. Iskak Tulungagung menunjukkan terjadinya coercive isomorphism, yaituisomorphism yang terjadi akibat adanya tekanantekanan formal ataupun informal yang diterima suatu organisasi, meskipun bisa dikatakan sebagai gejala yang lemah karena pada perkembangan selanjutnya tidak terdapat lagi tekanan tersebut. Selain itu, juga terdapatgejala mimetic ishomorphism, yaitu isomorphism yang terjadi ketika sebuah organisasimeniru 
New

Institutional

Theory...

604

praktek yang ada pada organisasi lain yang dinilai lebih baik dan berhasil, sebagaipendukung dan pelengkap tekanan coercive yang telah ada sebelumnya. Normative ishomorphism merupakan gejala yang paling dominan dalam proses penyusunan RBA, yaitu isomorphism yang menekankan profesionalisasi organisasi sebagai faktor pendorong perubahan. Norma atau sesuatu yang tepat bagi organiasi berasal dari sosialisasi yang menyokong dan menyebarkan kepercayaan normatif itu.

Penerapan anggaran berbasis kinerja dalam proses penyusunan RBA di RSUD dr. Iskak Tulungagung telah mendorong terjadinya perubahan organisasi, mulai dari perubahan struktur organisasi, SDM, prosedural, sampai pada perubahan nilai-nilai manajemennya. Salah satu dampak paling menonjol dari penerapan anggaran berbasis kinerja di RSUD dr. Iskak Tulungagung adalah keleuasaan untuk menyusun anggaran sesuai dengan kebutuhan, sehingga penggunaan dana lebih efektif dan efisien. Efektifitas dan efisiensi dana memberi peluang rumah sakit untuk mendapatkan keuntungan yang lebih tinggi.

\section{Keterbatasan Penelitian Dan Saran Untuk Penelitian Berikutnya}

Penelitian ini dilakukan terhadap proses penyusunan anggaran di RSUD dr. Iskak Tulungagung. Dalam pelaksanaannya penyusunan anggaran (RBA) BLUD dilakukan secara berjenjang dengan melibatkan hingga ke unit-unit kerja terkecil pengguna anggaran, namun demikian karena keterbatasan waktu peneliti hanya dapat melakukan pengamatan pada proses penyusunan anggaran di tingkat kompilasi usulan anggaran hingga menjadi dokumen RBA oleh tim penyusun anggaran saja. Penelitian belum dilakukan dengan melakukan pengamatan lebih dalam terhadap proses pengajuan usulan anggaran oleh unit-unit kerja kepada Pejabat Pelaksanan Teknis Kegiatan (PPTK) setiap bidang karena penelitian ini dilakukan di bulan Desember-Januari sementara usulan anggaran kepada PPTK telah disampaikan bulan Oktober-November.

\section{DAFTAR PUSTAKA}

Abernethy, M. A., Chua, W. F., Grafton, J., \& Mahama, H. (2007). "Accounting and Control in Health Care: Behavioural, Organisational, Sociological and Critical Perspectives". Handbook of Management Accounting Research, Volume 2, pp. 805-829.

Arndt, M., \& Bigelow, B. (2000). "The Transfer of Business Practices Into Hospitals: History and Implications". Health Care Management, Volume 1, pp. 339368.

Bastian, I. (2006). Akuntansi Sektor Publik: Suatu Pengantar. Erlangga. Jakarta.

Burnes, B. (1997). "Organizational choice and organizational change, Management Decision". Volume 35, No.10, pp. 753-759.

Carruthers, B. G. (1995). "Accounting, Ambiguity, and The New Institutinalism. Accounting, Organizational and Society”. Volume 20, No. 4, pp. 313-328.

Chua, W. F., \& Preston, A. (1994). "Worrying about Accounting in Health Care. Accounting". Auditing \& Accountability Journal, Volume 7, No. 3, pp. 4 - 17.

Covaleski, M. A., Dirsmith, M. W., \& Michelman, J. E. (1993). "An Institutional Theory Perspective on The DRG Framework, Case-Mix Accounting Systems And Health-Care Organizations". Accounting, Organizations and Society, Volume 1, No. 1, pp. 65-90.

Curristine, T. (2005). "Government Performance: Lessons and Challenges OECD”. Journal on Budgeting, Volume 5, No. 1. 
Curristine,T., Lonti, Z., \& Joumard, I. (2007). "Improving Public Sector Efficiency: Challenges and Opportunities OECD”. Journal on Budgeting, Volume 7, No. 1.

DiMaggio, J. P., \& Powell, W. W. (1983). "The Iron Cage Revisited: Institutional Isomorphism and Collective Rationality in Organizational Field". American Sosiological Review, Volume 48, No. 2, pp. 147-160.

DiMaggio, J. P., \& Powell, W. W. (1991). The New Institutionalism in Organizational Analysis. The University of Chicago Press. Chicago.

Hassan, M. K. (2005). "Management accounting and organisational change: an institutional perspective". Journal of Accounting \& Organizational Change, Volume 1, No. 2, pp. 125-140.

Hood, C. (1991). "A Public Management for All Season”. Public Administratio, Volume 69 , pp. 3 - 19.

Hood, C. (1995). "The New Public Management in "the 80's": Variations on a theme". Accounting, Organization and Society, Volume 20, No. 2/3, pp. 93 - 109.

Hopwood, G. A. (1990). "Accounting and Organisation Change". Accounting \& Accountability Journal, Volume 3, No. 1, pp. 7-17

Jones, G. R. (2001). Organizational Theory Text and Cases. Prenctice Hall International Inc. New Jersey.

Kitchener, M., \& Whipp, R. (1996). "Tracks of change in hospitals:a study of quasimarket transformation". Journal of Management in Medicine, Volume 12, No. 4/5 1998, pp. 241-255.

Koppell, J. G. S. (2003). The Politics of Quasi-Government: Hybrid Organizations and the Dynamics of Bureaucratic Control. Cambridge University Press.

Lehtonen, T. (2007). "DRG-based prospective pricing and case-mix accountingExploring the mechanisms of successful implementation". Management Accounting Research, Volume 18, pp. 367-395.

Lewin, K. (1951). Field Theory in Social Science. Harper and Row. New York.

Lippi, A. (2000). "One Theory, Many Practices. Institutional Allomorphism in The Managerialist Reorganization of Italian Local Governments". Scandinavian Journal of Management, Volume 16, No. 4, pp. 455-477.

Mardiasmo. (2009). Akuntansi sektor publik. Andi. Yogyakarta.

Miles, M. B., \& Huberman, A. M. (1984). Qualitative Data Analysis: A Sourcebook of New Methods. Sage Publications.

Moynihan, D. P. (2003). "Performance-based budgeting: beyond rhetoric". Poverty Reduction and Economic Management Notes. No. 78, February 2003.

Powell, W. W.( 2007). The New Institutionalism. The International Encyclopedia of Organization Studies. Sage Publishers.

Putranto, Y. A, (2012). "Pengaruh Moderasi Informasi Asimetri dan Group Cohesiveness Terhadap Hubungan Partisipasi Penganggaran Dengan Budgetary Slack'. Jurnal Economia, Volume 8, Nomor 2, Oktober 2012.

Republik Indonesia, Peraturan Menteri Dalam Negeri No. 61 Tahun 2007 tentang Pedoman Teknis Pengelolaan Keuangan Badan Layanan Umum Daerah.

Republik Indonesia, Undang-Undang No. 24 Tahun 2011 tentang Badan Penyelenggara Jaminan Sosial.

Robbins, S. P., \& Judge, T. (2015). Organizational Behavior. Pearson. New Jersey. Terjemahan Ratna Saraswati dan Febriella Sirait. Perilaku Organisasi. Edisi keenambelas. Salemba Empat. Jakarta.

Robinson, M., \& Brumby, J. (2005). "Does Performance Budgeting Work? An Analytical Review of the Empirical Literature". IMF Working Paper, Fiscal Affairs Department. November 2005. 
New

Institutional

Theory...

606
Scott, W. R. (2014). W. Richard Scott (1995). "Institutions and Organizations". Ideas, Interests and Identities.M@n@gement, Volume 17, No.2, pp. 136-140.

Setioko, B. (2011). Penggunaan Metoda Grounded Theory Dibawah Payung Paradigma Post-Positivistik Pada Penelitian Tentang Fenomena Sosial Perkotaan. Modul. 11 (1): 1-6.

Siddiquee, N. A. (2006). "Public Management Reform in Malaysia recent initiatives and experiences". International Journal of Public Sector Management, Volume 19, No. 4, pp. 339-358.

Stamatiadis, F., \& Eriotis, N. (2011). "Evolution of the Governmental Accounting Reform implementation in Greek Public Hospitals: Testing the institutional framework". Paper prepared to be presented in the 34th Annual Congress of the European Accounting Association Rome, 20-22 April 2011.

Yin, R. K. (2014). Studi Kasus: Desain dan Metode (M. D. Mudzakkir, Trans.). Rajawali Pers. Jakarta.

Young, R. D. (2003). "Performance-Based Budget Systems". USC Institute For Public Service And Policy Research - Public Policy \& Practice. January 2003. 
